\title{
Uppermost Jurassic-Lower Cretaceous carbonate deposits from Fara San Martino (Maiella, Italy): biostratigraphic remarks
}

\author{
Roberta BRUNI ${ }^{1}$, Ioan I. BUCUR ${ }^{2}$ \& Alain PREAT ${ }^{3}$ \\ ${ }^{1}$ Via Togliatti 110b, 60127 Ancona, Italia \\ ${ }^{2}$ Department of Geology, „Babeș-Bolyai“ University, Kogălniceanu 1, 400084 Cluj Napoca, Romania \\ ${ }^{3}$ Université Libre de Bruxelles, Département des Sciences de la Terre et de l'Environnement, Géologie-CP160/02, 50 av FD \\ Roosevelt, Bruxelles B 1050, Belgique.
}

Received June 2007; accepted September 2007

Available online: 12 September 2007

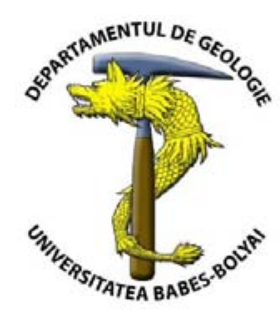

\begin{abstract}
The Uppermost Jurassic-Lower Cretaceous limestone succession in the Maiella region of Italy has been investigated in a profile covering more than $400 \mathrm{~m}$ stratigraphical thickness at Fara San Martino. The succession mainly consists of peritidal limestones, intertidal and supratidal sequences being dominant, together with subtidal lagoonal facies. As a consequence, the microfossil assemblages are generally poorly developed, Microfossils occur within the subtidal lagoonal facies of this suite of restricted sediments. This feature led us to recognise five informal biostratigraphic intervals, which are facies related - instead of biozones, each of the intervals being characterized by specific micropaleontological associations. The occurrence and/or disappearance of some marker microfossils were used as references for separating these intervals. Based on these markers, the Uppermost Jurassic-Lower Cretaceous carbonate deposits from Maiella region may be correlated with similar deposits from the Apennines and from other regions in the perimediterranean area.
\end{abstract}

Key words: Calcareous algae, Foraminifers, Biostratigraphy, Lower Cretaceous, Maiella, Italy.

\section{INTRODUCTION}

The data presented in this paper are part of a larger multidisciplinary stratigraphic study (sedimentology, sequence stratigraphy, and isotopic geochemistry) presented by one of the authors (R.B.) as part of a PhD thesis at the Université Libre de Bruxelles. Two Lower Cretaceous sections from Italy, one located in Frioul (Val Celina section), and another one, included in this paper, in Maiella were investigated as part of this PhD study.

The Fara San Martino section in Maiella allows a very good access to an internal platform carbonate succession covering the Upper Jurassic (Tithonian) - Aptian interval. The Maiella massif was the object of numerous stratigraphic studies (Accarie et al., 1986; Accarie, 1988; Anselmetti et al., 1997; Bernoulli et al., 1996; Eberli et al., 1993; Lampert et al., 1997 and Vecsei, 1991) that focused on the Upper Cretaceous slope deposits but were less specific concerning the Lower Cretaceous platform. As a result, this carbonate platform was very poorly investigated.

This paper illustrates the organisms identified during a detailed biostratigraphic study that allowed the separation of various intervals in spite of the scarcity of the microfossils. This microfaunal depletion is related to the sedimentary system, which is an internal platform that was wellprotected from the open sea, where intertidal and supratidal facies interlayered with frequent levels of calcretes and dolocretes (paleosoils) dominated. The identified organisms were most typically present in subtidal lagoon-type environments located between a distal barrier and the often emersed littoral domain (Bruni, 2003).

The Fara San Martino section shows an exceptional stratigraphic continuity over more than $400 \mathrm{~m}$ thickness, the beds being displayed subvertical or slightly inclined, allowing systematic sampling. The section has been investigated individually for each bank, a number of 360 oriented samples being collected with an average frequency of one sample per one meter stratigraphic thickness.

\section{LOCATION AND STRATIGRAPHIC FRAMEWORK}

The Fara San Martino section is located close to the Fara San Martino village, in the proximity of the San-Martino river gorges (Fig.1). This section, also studied by Crescenti (1969) and Acarie (1980) covers the Upper Jurassic pro parte - Aptian pro parte interval.

From a lithostratigraphic point of view, the internal platform limestones of Liassic to Lower Cretaceous ages are assigned to a single formation, i.e. the Morrone di Pacentro Limestone Formation (Crescenti, 1969; Crescenti et al., 1969). This formation is about $600 \mathrm{~m}$ thick, of which the first $100 \mathrm{~m}$ crop out only partially at regional scale. At Fara San Martino, the Cretaceous succession is $400 \mathrm{~m}$ thick. 


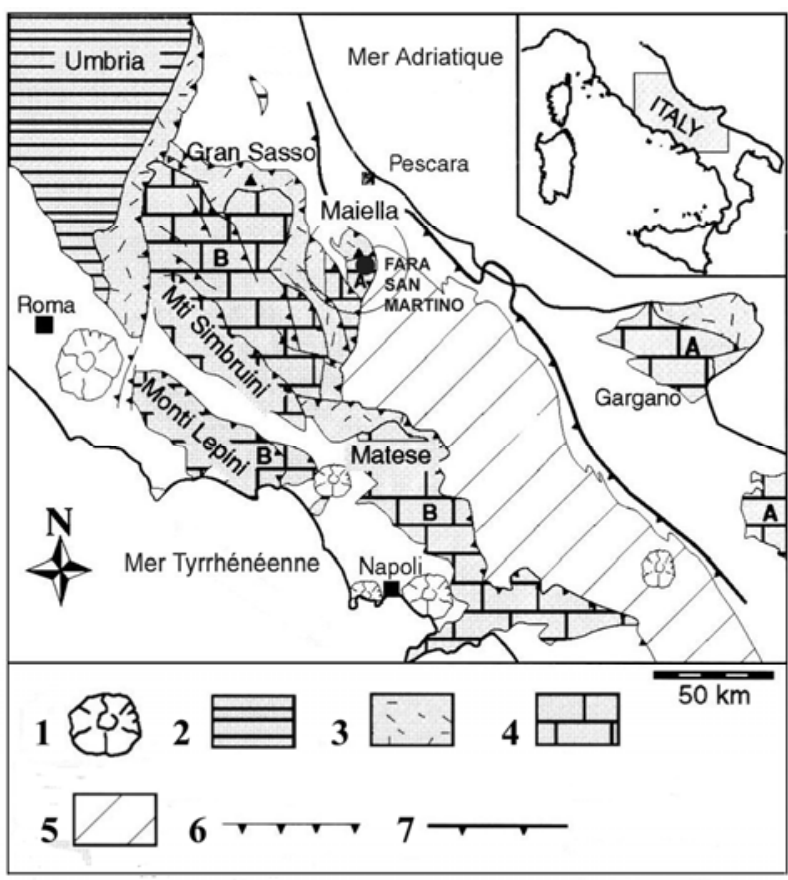

Fig. 1. Geographic location of the Maiella massif and occurrence of the main geologic formations. 1- Quaternary;

2-pelagic sediments; 3-carbonate turbidites; slope and toe-of-

slope; 4-carbonate platforms: A-Apulia, B-Latium-Abruzzo;

5-internal allochtonous units; 6-overthrust;

7-front of allochtonous units (subsurface).

The lower limit of the formation cannot be observed at Fara San Martino, while the upper limit is represented by a bauxitic episode, rich in pisolites associated with micritic limestones and calcareous breccias. The stratigraphic hiatus connected to the bauxites extends from the Middle-Upper Albian to the Middle Cenomanian (Acarie \& Delamette, 1991). The Morrone di Pacentro Formation consists of a typical, low energy internal platform succession (peritidal environment) located behind a platform edge constructed by rudists, where the energy was higher (Bruni, 2003).

Crescenti et al. (1969) separated the following three biozones within the Upper Jurassic -Aptian succession from Fara san Martino: a biozone with Clypeina jurassica and Vaginella striata, a biozone with Salpingoporella appeninica, and a biozone with Cuneolina camposaurii. Acarie (1988) reconsidered the above mentioned subdivisions and the general interpretation of the internal platform. He was the first author who insisted on the "indistinctive" feature of the stratification, which he however presented as organised into units about $20 \mathrm{~m}$ thick. This author considered a cyclic development for these deposits, the cycles or "sequences" being asymmetrical and showing a general "shallowing upward" evolutionary trend.

\section{BIOSTRATIGRAPHIC ANALYSIS}

The taxa considered as references for the biostratigraphic separation were selected among the most frequent (but never abundant!) forms that are, at the same time, easy to be identified. In this study we preferred to defined biostratigraphic intervals rather than biozones that might have shown a more restrained vertical development, but that could have been problematic in their identification.

Thus, five informal intervals (presented below as A, B, C, D, and E) have been defined for this study (Fig. 2). The limits of the intervals are marked by the occurrence and disappearance of the marker microfossils (Fig. 3).

In a normal stratigraphical succession, these intervals are:

\section{Interval A}

This interval is delimited by the base of the section and respectively by the occurrence of Protopeneroplis ultragranulata, the oldest foraminifer identified in the section. Interval A is dominated, especially in its lower and medium part, by levels with coprolites assignable to genus Favreina, and by ostracod levels. Two coprolite species are present: Favreina salevensis (PAREJAS) and Favreina njegosensis BRONNIMANN. Numerous dasycladalean fragments and rivulariacean-type cyanobacteria (Cayeuxia sp.), large fragments of gastropods, ostracods and rare small biseriate foraminifers are sometimes associated with the coprolites.

Association: Favreina salevensis PAREJAS, Favreina njegosensis BROENNIMANN, Clypeina sulcata (ALTH) (Pl. 1, Figs. 1, 2, 4), Campbelliella striata (CAROZZI), Salpingoporella cf. annulata CAROZZI (Pl. 1, Fig. 3), Salpingoporella sp. (Pl. 1, Fig. 6), Clypeina parasolkani FARINACCI and RADOIČIĆ (P1. 1, Figs. 5, 14), Humiella sp. (Pl. 1, Fig. 7), Marinella cf. lugeoni, Bolivinopsis sp., ?Andersenolina sp., miliolids, ostracods, fragments of gastropods and bivalves, and stromatolites.

Location: from $\mathrm{m} 0$ to $\mathrm{m} 145$.

Age: Uppermost Jurassic -Berriasian. The association mainly contains calcareous algae known from the Upper Jurassic -Berriasian interval (Granier and Deloffre, 1993; Bucur, 1999). The presence of Berriasian within the interval A is confirmed by the common presence of Clypeina parasolkani FARINACCI and RADOIČIĆ.

\section{Interval B}

This interval is defined by the occurrence of Protopeneroplis ultragranulata (GORBACHIK). The species occurs a few meters below the first Vercorsella. It is followed by the occurrence of Montsalevia salevensis CHAROLLAIS, BROENNIMANN \& ZANINETTI. The top of the interval is marked by the occurrence of Campanellula capuensis DE CASTRO. The interval is about $120 \mathrm{~m}$ thick and the deposits are scarce in foraminifers (small biseriate foraminifers and miliolids). Some levels rich in foraminifers and dasycladalean algae occur in its lower beds. Salpingoporella annulata has been identified associated with levels rich in Favreines in the lower part of the interval, below the Protopeneroplis ultragranulata level.

Association:

Protopeneroplis

ultragranulata (GORBACHIK) (Pl. 3, Figs. 5, 6), Vercorsella camposaurii (SARTONI and CRESCENTI) (Pl. 3, Figs. 10, 11), Montsalevia salevensis (CHAROLLAIS, BROENNIMANN and ZANINETTI), (Pl. 3, Figs. 1, 2) Haplophragmoides joukowskyi (CHAROLLAIS, BROENNIMANN and ZANINETTI) (Pl. 3, Figs. 3, 4), Giraliarella? prismatica ARNAUD VANNEAU, Earlandia? conradi ARNAUDVANNEAU, Praechrysalidina infracretacea LUPERTO SINNI (P1. 3, Figs. 21, 22), Rumanoloculina multicostata NEAGU, Andersenolina sp., Belorusiella sp., Vercorsella sp., Salpingoporella annulata CAROZZI, Favreina salevensis (PAREJAS), miliolids, ostracods, crinoids, fragments of gastropods and bivalves.

Location: from m 145 to $\mathrm{m} 264$. 


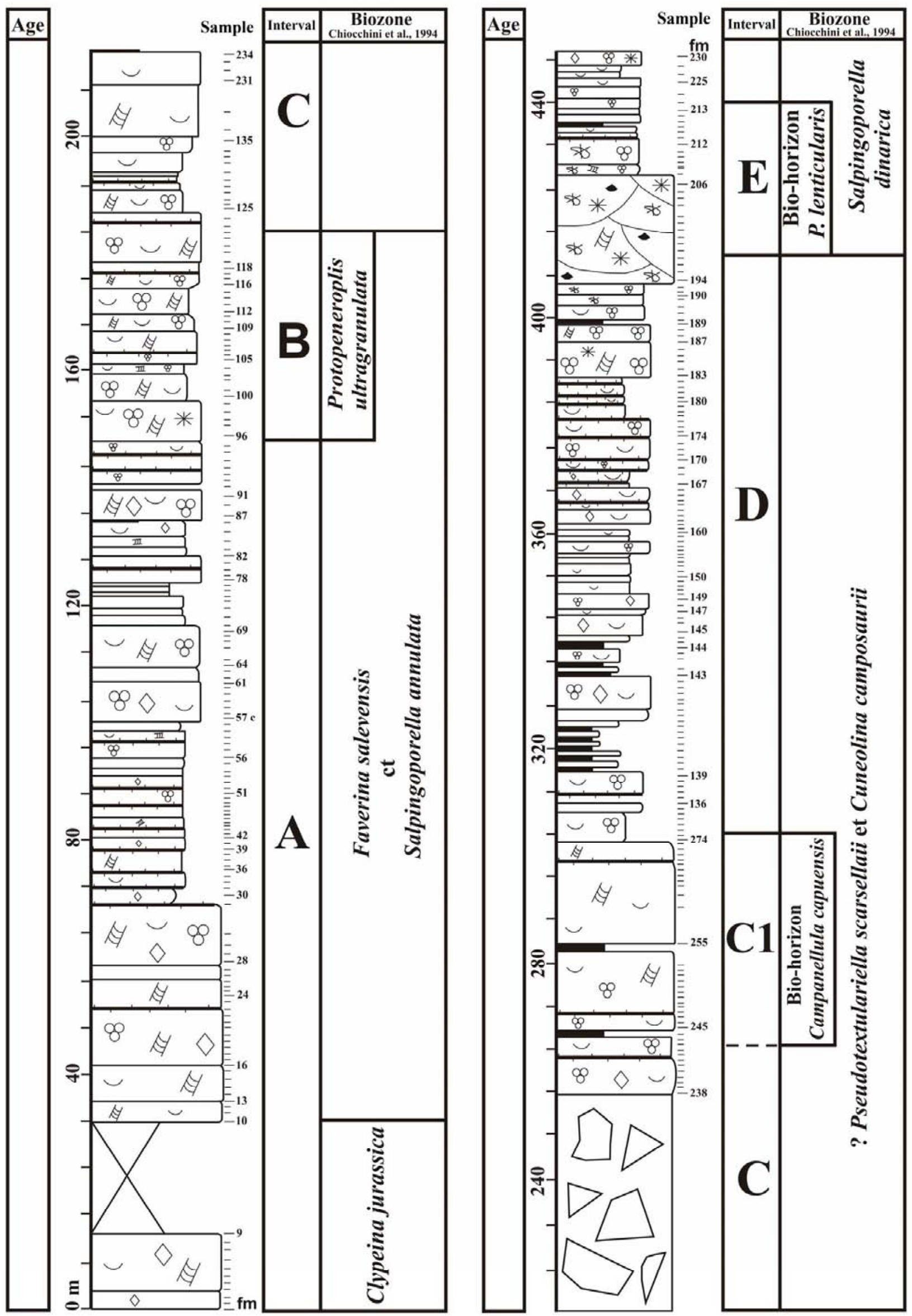

Fig. 2. Succession of carbonate deposits from Fara San Martino, and delimitation of the five biostratigraphic intervals $(A-E)$. (for legend, see page 49). 


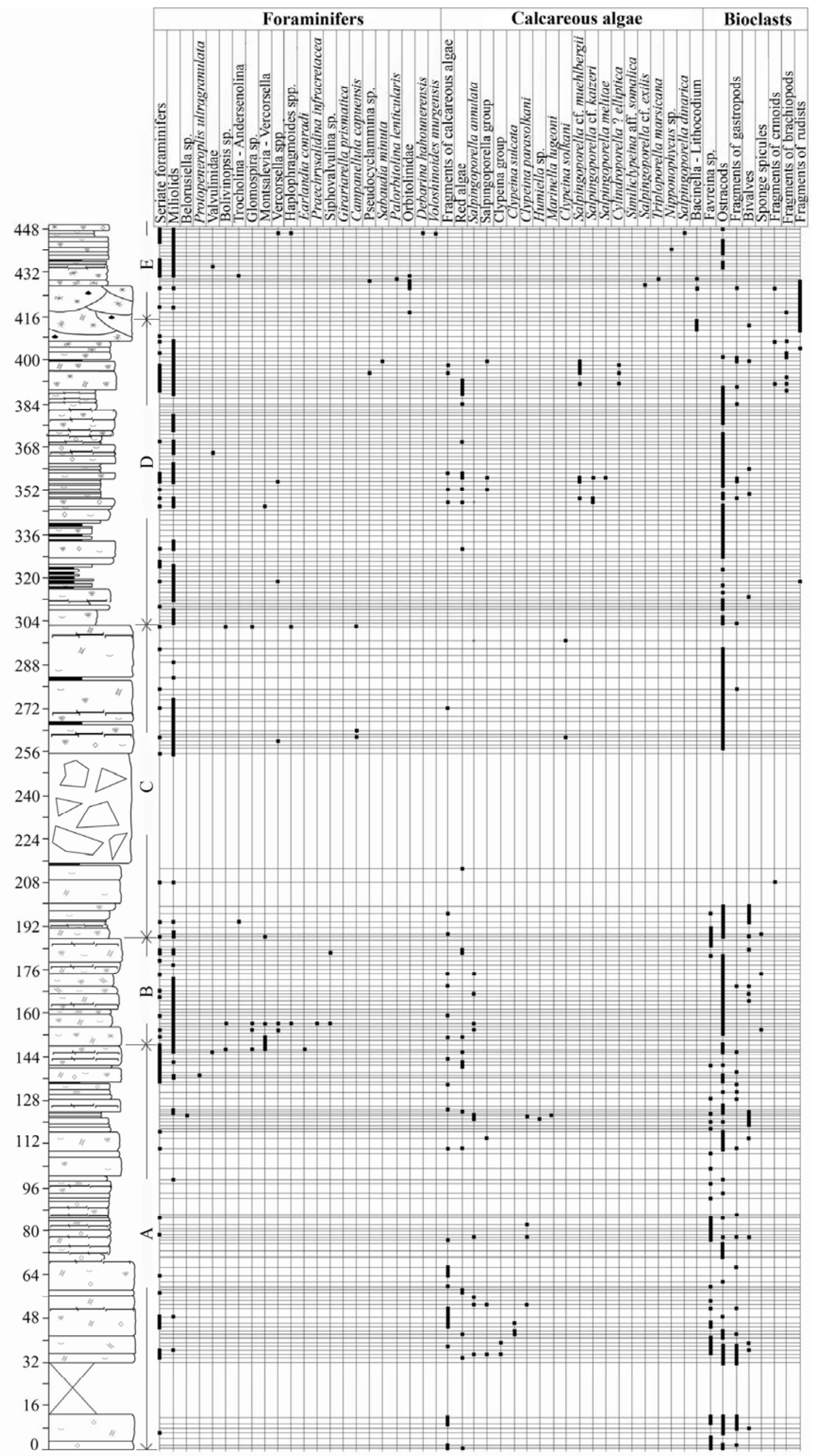


Fig. 3. (opposite page) Vertical distribution of the main microfossils identified in the limestones from Fara San Martino and their relationship with the five biostratigraphic intervals. For explanation of symbols, see bellow.

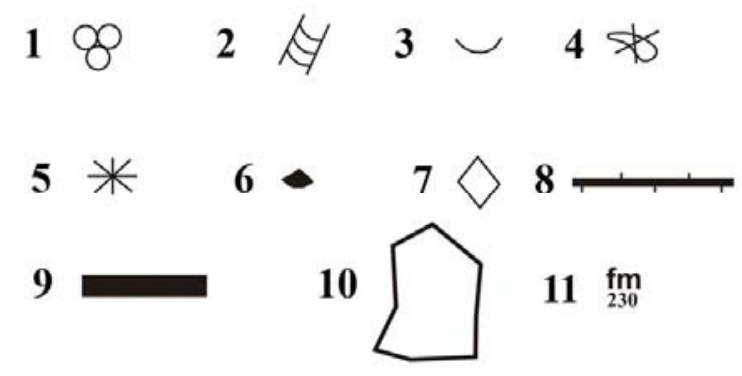

Explanation of the symbols used in Figs. 2 and 3.

1-foraminifers; 2-dasycladalean algae; 3-ostracods; 4-rudists; 5-crinoids; 6-orbitolinids; 7-dolomite; 8-paleosols;

9-mm to cm-size joints; 10-breccia; 11-sample number.

Age: Berriasian-Valanginian. This interval contains a typical association of foraminifers. Even if the typical stratigraphic distribution for Protopeneroplis ultragranulata is the Middle Tithonian-Barremian interval (Heinz and Isenschmid, 1988; Bucur, 1993, 1997), the most frequent occurrence for this species is however represented by the Berriasian-Lower Valanginian interval (Azema et al., 1977; Azema et al., 1979; Salvini-Bonnard et al., 1984; Boisseau, 1987; Granier, 1987; Zaninetti et al., 1988; Bucur, 1988; Chiochinni et al., 1988; Velic, 1988; Bucur et al., 1995). In southern Italy, $P$. ultragranulata was assigned to the Berriasian (Luperto Sinni and Masse, 1986).

$H$. joukowskyi has been described from Valanginian (Charollais et al., 1966) and it was refound in BerriasianValanginian deposits by Darsac (1983), Boisseau (1987), Bucur et al. (1995), Ivanova (2000). The species was also reported from Hauterivian limestones (Bucur, 1988; Altiner, 1991).

M. salevensis, described from the same interval as $H$. joukowskyi (Charollais et al., 1966 as Pseudotextulariella salevensis) is more frequent in Valanginian deposits (Azema et al., 1977; Darsac, 1983; Chiocchini et al., 1988: Altiner, 1991; Bucur et al., 1995; Ivanova, 2000). The transfer of the species to genus Montsalevia (suggested by Zaninetti et al., 1987) was reinforced by Altiner (1991), Bucur et al. (1995), and Schroeder et al. (2000).

\section{Interval C}

This interval is defined by the occurrence and respectively the disappearance of species Campanellula capuensis DE CASTRO. In general, the interval is scarce in foraminifers and dasycladalean algae but very rich in ostracods.

Association: Campanellula capuensis DE CASTRO (Pl. 3, Figs. 7, 8, 9), Haplophragmoides joukowskyi (CHAROLLAIS, BRONNIMANN \& ZANNINETTI), Salpingoporella annulata CAROZZI, Clypeina solkani (CONRAD \& RADOIČIĆ) (P1. 2, Fig. 1), Glomospira sp., miliolids and ostracods.

Location: from $\mathrm{m} 265$ to $\mathrm{m} 305$.

Age: Hauterivian. According to De Castro (1964), the levels with Campanellula capuensis are located between Valanginian and Barremian. Macoin et al. (1970) considered this species as belonging to the Barremian, while Schroeder et al. (1978) to the Lower Barremian. Finally, Bodrogi et al. (1994) reported this species from Upper Hauterivian-Lower Barremian deposits.

In southern Italy, Luperto Sinni and Masse (1984, 1986) have separated a biozone with Orbitolinopsis? capuensis that they have assigned to the Hauterivian. Claps et al. (1996) have made the same assignment for the species from deposits in Gargano (Pulia, southern Italy). The association accompanying $C$. capuensis in the Fara San Martino section (H. joukowskyi, S. annulata, and C. solkan) seems to confirm a Hauterivian age for this interval.

\section{Interval D}

This interval is defined by the disappearance of Campanellula capuensis to the occurrence of the orbitolinid level. Interval D is scarce in microfauna, especially in its basal part, where some miliolids and numerous ostracods are present. Sporadically also levels rich in dasycladaleans and foraminifers were noticed.

Association: Salpingoporella muhelbergii (LORENZ) (P1. 2, Figs. 7, 8), Salpingoporella cf. muhelbergii (LORENZ), Salpingoporella cf. katzeri CONRAD \& RADOIČIĆ (Pl. 1, Figs. 15-18), Clypeina solkani CONRAD \& RADOIČIĆ, Salpingoporella melitae (RADOIČIĆ) (Pl. 2, Fig. 2), Cylindroporella? elliptica BAKALOVA sp. (Pl. 2, Fig. 4), Similclypeina aff. somalica (CONRAD, PEYBERNES \& MASSE) (Pl. 2, Fig. 14), Sabaudia minuta (HOFKER) (Pl. 3, Figs. 12-15), Pseudocyclammina sp., Bolivinopsis sp., Pseudolituonella sp., Comaliammina sp., miliolids, ostracods, fragments of gastropods and bivalves, crinoids, sponge spicules and stromatolites.

Location: from $\mathrm{m} 305$ to $\mathrm{m} 405$.

Age: Barremian. Even if numerous dasycladaleans in this association are typical for the whole Barremian-Aptian interval, the location of interval $\mathrm{D}$ between the levels with Campanellula capuensis and those with Palorbitolina lenticularis constitutes an argument for its Barremian age.

\section{Interval E}

This interval, defined based on the occurrence of Palorbitolina lenticularis, is characterized by the abundance of benthonic foraminifers, of rivulariacean-type cyanobacteria and especially by the large fragments of rudists belonging to genus Offrenia. The microfauna become scarcer towards the top of the interval, where only rare miliolids and ostracods are present. The upper limit corresponds to the top of the section.

Association: Palorbitolina (BLUMENBACH) (P1. 3, Fig. 19), Sabaudia minuta (HOFKER), "Trocholina” odukpaniensis (DESAUVAGIE), Pseudocyclammina sp. (Pl. 3, Fig. 23), Salpingoporella pygmaea (GUEMBEL) (P1. 2, Fig. 13), Triploporella marsicana PRATURLON (Pl. 2, Fig. 12), Bacinella irregularis RADOIČIĆ (P1. 2, Fig. 16), Lithocodium aggregatum ELLIOTT, ?Nypponophicus sp. (Pl. 2, Fig. 17), sponge spicules, large fragments of gastropods and bivalves including rudists (Offneria italica), crinoids and ostracods. At the upper part of this interval, a thin level is very rich in foraminifers and calcareous algae: Debarina hahounerensis FOURCADE, RAOUL \& VILA (P1. 3, Fig. 18), Vercorsella camposaurii (SARTONI \& CRESCENTI), 
Vercorsella laurentii (SARTONI \& CRESCENTI) (Pl. 3, Fig. 20), Voloshinoides murgensis LUPERTO SINNI \& MASSE (P1. 3, Fig. 17), Salpingoporella dinarica RADOIČIĆ (Pl. 2, Figs. 9, 10), Thaumatoporella parvovesiculifera (RAINERI).

Location: from m 413 to $\mathrm{m} 440$.

Age: Aptian. Palorbitolina lenticularis covers the Upper Barremian-Lower Aptian interval (Schroeder et al., 1978). In southern Italy, this species is typical for the Lower Aptian only (Cherchi et al., 1978; Luperto Sinni and Mase, 1986, 1992; Chiocchini et al., 1994), where it is associated with Sabaudia minuta, Debarina hahounerensis, Voloshinoides murgensis and Salpingoporella dinarica.

\section{CONCLUSIONS}

The micropaleontological analysis of the Upper JurassicLower Cretaceous carbonate succession from the Fara San Martino section (Maiella) led us to the identification of several micropaleontological associations that allowed the separation of five informal stratigraphic intervals. Each of these intervals is characterized by the occurrence and/or disappearance of marker microfossils and each contains a micropaleontological association that is characteristic for a certain age: Uppermost Jurassic -Berriasian - in the case of interval A; Berriasian-Valanginian - for interval B; Hauterivian - for interval C; Barremian - for interval D, and Lower Aptian - for interval E. The micropaleontological associations are scarce and poorly diversified; they are similar to those of other Mediterranean areas and show an equivalent vertical distribution. These associations may be used for regional scale correlations, but also for general correlations in the whole perimediterranean area.

Acknowledgments. The study was partly funded by CNCSIS, Romania (grant 1330 to I.B.). We thank Dana Pop for the English version of the text and Alin Igrițan for redrawing Fig. 2. We also thank Steve Kershaw and Bernard Mamet for reviewing the paper and improving the English text.

\section{R E F E R E N C E S}

Accarie, H. 1988, Dynamique sédimentaire et structurale au passage plate-forme-bassin. Les faciès carbonatés crétacés et tertiaires: Massif de la Maiella (Abruzzes, Italie). Ecole des Mines de Paris, Mémoire des Sciences de la Terre, 5: $162 \mathrm{pp}$.

Accarie, H., Beaudoin, B., Cussey, R., Joseph, P. \& Triboulet, S. 1986, Dynamique sédimentaire et structurale au passage plate-forme/ bassin, les faciès carbonates crétacés du massif de la Maiella (Abruzzes, Italie). Memorie della Societa Geollogica Italiana, 36: 217-231.

Accarie, H., Delamette, M. 1991, Découverte d'ammonites albiennes dans le massif apennin de la Maiella (plateforme lazio-abruzzaise, Italie Centrale); précision sur la durée du hiatus bauxitique médio-crétacé. Cretaceous Research, 12 (1): 81-90.

Altiner, D. 1991, Microfossil biostratigraphy (mainly foraminifers) on the Jurassic-Lower Cretaceous carbonate successions in north-western Anatolia (Turkey). Geologica Romana, 27: 167-213.
Anselmetti, F.S., Eberli, G.P. \& Bernoulli, D. 1997, Seismic modeling of a carbonate platform margin (Montagna della Maiella, Italy): variations in seismic facies and implications for sequence stratigraphy. In Carbonate Seismology (Marfurt, F.J., Palaz, A., Eds.), SEG Geophysical Developments Series 6: 373-406.

Azema, J., Chabrier, G., Fourcade, E. \& Jaffrezo, M. 1977, Nouvelles données micropaléontologiques, stratigraphiques et paléogéographiqies sur le Portlandien et le Néocomien de Sardaigne. Revue de Micropaléontologie, 20 (3): 125-139.

Azema, J., Chabrier, G., Chauve, P. \& Fourcade, E. 1979, Nouvelles données stratigraphiques sur le Jurassique et le Crétacé du Nord-Ouest d'Ibiza (Baleares, Espagnes). Geologica Romana, 18: 1-21.

Bernoulli, D., Anselmetti, F.S., Eberli G.P., Mutti, M., Pignatti, J.S., Sanders D.G.K. \& Vecsei, A. 1996, Montagna della Maiella: the sedimentary and sequential evolution of a Bahamian-type carbonate platform of the South-Tethyan continental margin. Memorie della Sococieta Geologica Italiana, 51 (3): 7-12.

Bodrogi I., Bona J. \& Lobitzer H. 1994, Vergleichende Untersuchung der Foraminiferen- und KalkalgenAssoziationen der Urgon-Entwiklung des Schrattenkalks in Voralberg (Oesterreich) und der Nagyharsany Kalkstein Formation des Villany-Gebirges (Ungarn). Jubilaeumschrift 20 Jahre Geologische Zusammenarbeit Oesterreich-Ungarn, 2: 225-283.

Boisseau, T. 1987, La plate-forme jurassienne et sa bordure subalpine au Berriasien-Valanginien (ChartreuseVercors). Analyse et corrélation avec les séries de bassin. Thèse de Doctorat, Université de Grenoble, 413 p.

Bruni, R. 2003, Stratigraphie du Crétacé inférieur de la Maiella (Abruzzes) et des Prealpes (Frioul), Italie. Thèse de Doctorat, Université Libre de Bruxelles, 237 p.

Bucur, I.I. 1988, Les foraminifères du Crétacé inférieur (Berriasien-Hauterivien) de la zone de Reşița-Moldova Nouă (Carpathes Méridionales, Roumanie). Remarques biostratigraphiques. Revue de Paléobiologie, Special Volume 2 (Benthos '86): 379-389.

Bucur I.I. 1993, Les représentants du genre Protopeneroplis Weynschenk dans les dépôts du Crétacé inférieur de la zone de Reşiţa-Moldova Nouă (Carpathes Méridionales, Roumanie). Revue de Micropaléontologie, 36 (3): 213-223.

Bucur, I.I. 1997, Representatives of the genus Protopeneroplis (Foraminifera) in the Jurassic and Lower Cretaceous deposits in Romania. Comparisons with other regions of the Tethyan area. Acta Palaeontologica Romaniae, I: 65-71.

Bucur, I.I. 1999, Stratigraphic significance of some skeletal calcareous algae (Dasycladales, Caulerpales) of the Phanerozoic. In Depositional Episodes and Bioevents (Farinacci A., Lord A.R., Eds). Palaeopelagos, Special Publication 2: pp. 53-104.

Bucur, I.I., Conrad, M.A. \& Radoičić, R. 1995, Foraminifers and calcareous algae from the Valanginian limestones in the Jerma River Canyon, Eastern Serbia. Revue de Paléobiologie, 14 (2): 349-377.

Charollais, J., Broennimann, P. \& Zaninetti, L. 1966, Troisième note sur les Foraminifères du Crétacé inférieur de la région génovoise. Remarques stratigraphiques et description de Pseudotextulariella salevensis n. sp., Haplophragmoides joukowskyi n. sp.; 
Citaella? favrei n. sp. Archives des Sciences SPHN Geneve, 19 (1): 23-48.

Cherchi, A., De Castro P. \& Schroeder, R. 1978, Sull'età dei liveli a Orbitolinidi della Campania e delle Murge Baresi (Italia meridionale). Bollettino della Società dei Naturalisti in Napoli, 87: 1-27.

Chiocchini, M., Farinacci, A., Mancinelli, A., Molinari, V. \& Potetti, M. 1994, Biostratigrafia a foraminiferi, dasicladali e calpionelle delle successioni carbonatiche mesozoiche dell'Appennino centrale (Italia). Studi Geologici Camerti, Special Volume "Biostratigrafia dell'Italia centrale", pp. 9-128

Chiocchini, M., Mancinelli, A. \& Marcucci, C. 1988, Distribution of benthic foraminifera and algae in the Lazium-Abruzzi carbonate platform facies (Central Italy) during Upper Malm-Neocomian. Revue de Paléobiologie, Special Volume 2 (Benthos '86): 219-227.

Claps, M., Parente, M., Neri, C. \& Bosellini, A. 1996, Facies and cycles of the S. Giovanni Rotondo Limestone (Lower Cretaceous, Gargano Promontory, southern Italy): the Borgo Celano section. Annali dell'università di Ferrara, 7, supplement: 1-35.

Crescenti, U. 1969, Biostratigrafia delle facies mesozoiche dell'Appennino Centrale: correlazioni. Geologica Romana, 8: 15-20.

Crescenti, U., Crostella, A., Donzelli, G. \& Raffi G. 1969, Stratigrafia delle serie calcaree dal Lias al Miocene nella regione marchigiano-abruzzese. (Parte II. Litostratigrafia, biostratigrafia, paleogeografia). Memorie della Societa Geologica Italiana, 8: 343-420.

Darsac, C. 1983, La plate-forme berriaso-valanginienne du Jura méridional aux massifs subalpins (Ain, Savoie). Sédimentologie, minéralogie, stratigraphie, paléogéographie, micropaléontologie. Thèse $3 e$ cycle, Université de Grenoble: 319 p.

De Castro, P. 1964, Su di un nuovo foraminifero del Cretacico inferiore dell'Appennino meridionale. Bollettino della Società dei Naturalisti in Napoli, 73: 55-61.

Eberli, G.P., Bernoulli, D., Sanders, D. \& Vecsei, A. 1993, From aggradation to progradation: the Maiella platform (Abruzzi, Italy), In Cretaceous Carbonate Platforms (Simo, J.T., Scott, R.W. \& Masse, J.P., Eds.). American Association of Petroleum Geologists Memoir, 56: 213-232.

Farinacci, A., Radoičić, R. 1991, Late Jurassic-Early Cretaceous dasycladales (green algae) from the western Pontides, Turkey. Geologica Romana, XXVII: 135-165.

Granier, B. 1987, Le Crétacé inférieur de la Costa Blanca entre Busot et Altea, Alicante (Espagne): Biostratigraphie, Sédimentologie, Evolution tectonosédimentaire. Thèse de Doctorat; Mémoires des Sciences de la Terre, Université Pierre et Marie Curie, Paris, $281 \mathrm{p}$.

Granier, B., Deloffre, R. 1993, Inventaire critique des algues dasycladales fossiles. Ile partie - les algues dasycladales du Jurassique et du Crétacé. Revue de Paléobiologie, 12 (1): 19-65.

Heinz, R.A., Isenschmid, C.H. 1988, Microfazielle und stratigraphische Untersuchungen im Massivkalk (Malm) der Préalpes medians. Eclogae geologicae Helvetiae, 81 (1): 1-62.

Ivanova, D. 2000, Middle Callovian to Valanginian microfossil biostratigraphy in the west Balkan Mountain, Bulgaria (SE Europe). In Acta Palaeontologica Romaniae (Bucur I.I. \& Filipescu S., Eds.) II: 231-238.
Lampert, S.A., Lowrie, W., Hirt, A.M., Bernoulli, D. \& Mutti, M. 1997, Magnetic and sequence stratigraphy of redeposited Upper Cretaceous limestones in the Montagna della Maiella, Abruzzi, Italy. Earth and Planetary Science Letters, 150: 79-93.

Land, L.S., Behrens, E.W. \& Frishman, S.A. 1979, The ooids of Baffin Bay, Texas. Journal of Sedimentary Petrology, 49: 1269-1278

Luperto Sinni, E., Masse, J.P. 1984, Données nouvelles sur la micropaléontologie et la stratigraphie de la partie basale du "Calcare di Bari" (Crétacé inférieur) dans la région des Murges (Italie méridionale). Rivista Italiana di Paleontologia e Stratigrafia, 90 (3): 331-374.

Luperto Sinni, E., Masse, J.P. 1986, Données nouvelles sur la stratigraphie des calcaires de plate-forme du Crétacé inférieur du Gargano (Italie méridionale). Rivista Italiana di Paleontologia e Stratigrafia, 92 (1), 33-66.

Luperto Sinni, E., Masse, J.P. 1992, Biostratigrafia dell'Aptiano in facies di piattaforma carbonatica delle Murge baresi (Puglia - Italia meridionale). Rivista Italiana di Paleontologia e Stratigrafia, 98 (4): 403-424.

Macoin, P., Schroeder, R. \& Vila, J.-M. 1970, Campanellula capuensis DE Castro (Foram.), position systématique et réoartition stratigraphique en Algérie. IV Colloque Africain de Micropaléontologie, Editité par le Comité de Publication du Colloque, pp. 248-262.

Salvini-Bonnard, G., Zaninetti, L. \& Charollais, J. 1984, Les foraminifers dans le Crétacé inférieur (Berriasien moyen-Valanginien inférieur) de la region de la Corraterie, Grand-Salève (Haute Savoie, France): inventaire préliminaire et remarques stratigraphiques. Revue de Paléobiologie, 3 (2): 175-184.

Schroeder, R., Cherchi, A., Guellal, S. \& Vila, J.-M. 1978, Biozonation par les grands Foraminifères du Jurassique supérieur et du Crétacé inférieur et moyen des séries néritiques en Algérie NE. Considérations paléobiologiques. Annales de Mines et Géologie (Actes $\mathrm{du}$ VI-e Colloque Africain de Micropaléontologie, Tunis, 1974), 28 (2): 243-253.

Schroeder, R., Clavel, B., Conrad, M., Zaninetti, L., Busnardo, R., Charollais, J. \& Cherchi, A. 2000, Correlations biostratigraphiques entre la coupe d'Organyà (Pyrénées Catalanes, NE de l'Espagne) et le sud-Est de la France pour l'intervalle Valanginien-Aptien. Treballs del Museu de Geologia de Barcelona, 9: 5-41.

Vecsei, A. 1991, Aggradation und Progradation eines Karbonatplattform-Randes: Kreide bis mittleres Tertiär der Montagna della Maiella, Abruzzen. Mitteilungen aus dem Geologischen Institut der Eidgenössischen Technischen Hochschule und der Universität Zürich, Neue Folge, 294: 1-169.

Velic, I. 1988, Lower Cretaceous benthic foraminiferal biostratigraphy of the Shallow-water carbonates of the Dinarids. Revue de Paléobiologie, Special Volume 2 (Benthos'86): 467-475e.

Zaninetti, L., Charollais, J., Clavel, B., Decrouez, D., SalvinniBonnard, G. \& Steinhauser, N. 1988, Quelques remarques sur les fossiles du Salève (haute Savoie, France). Archives des Sciences SPHN Genève, 41 (1): 43-63.

Zaninetti, L., Salvini-Bonnard, G. \& Decrouez, D. 1987, Montsalevia, n. gen. (Montsaleviidae, n. fam., Foraminifère), dans le Crétacé inférieur (Berriasien moyen-Valanginien) du Mont Salève et du Jura Méridional (Haute-Savoie, France). Note préliminaire. Revue de Paléobiologie, 6 (1): 165-168. 

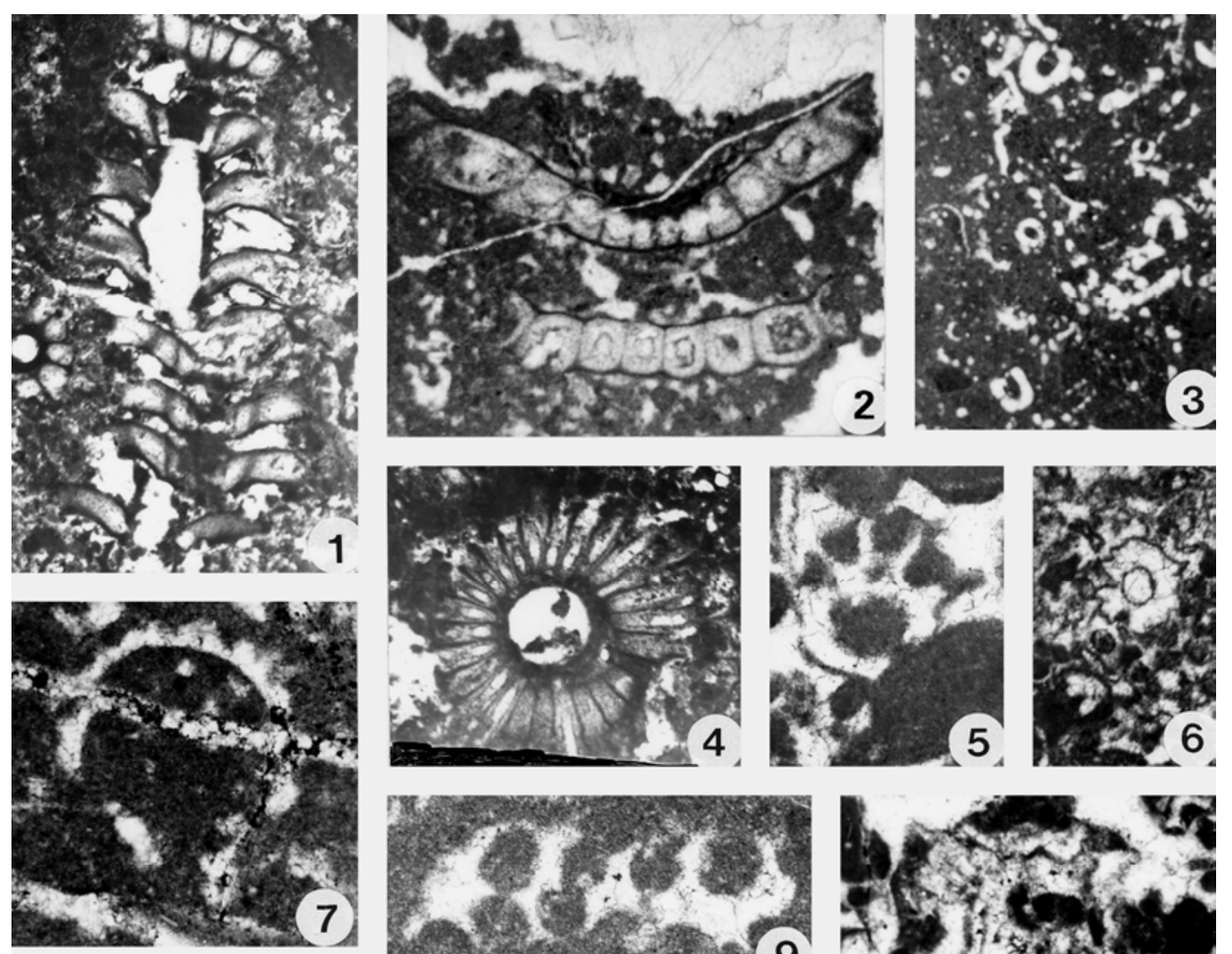

PLATE I
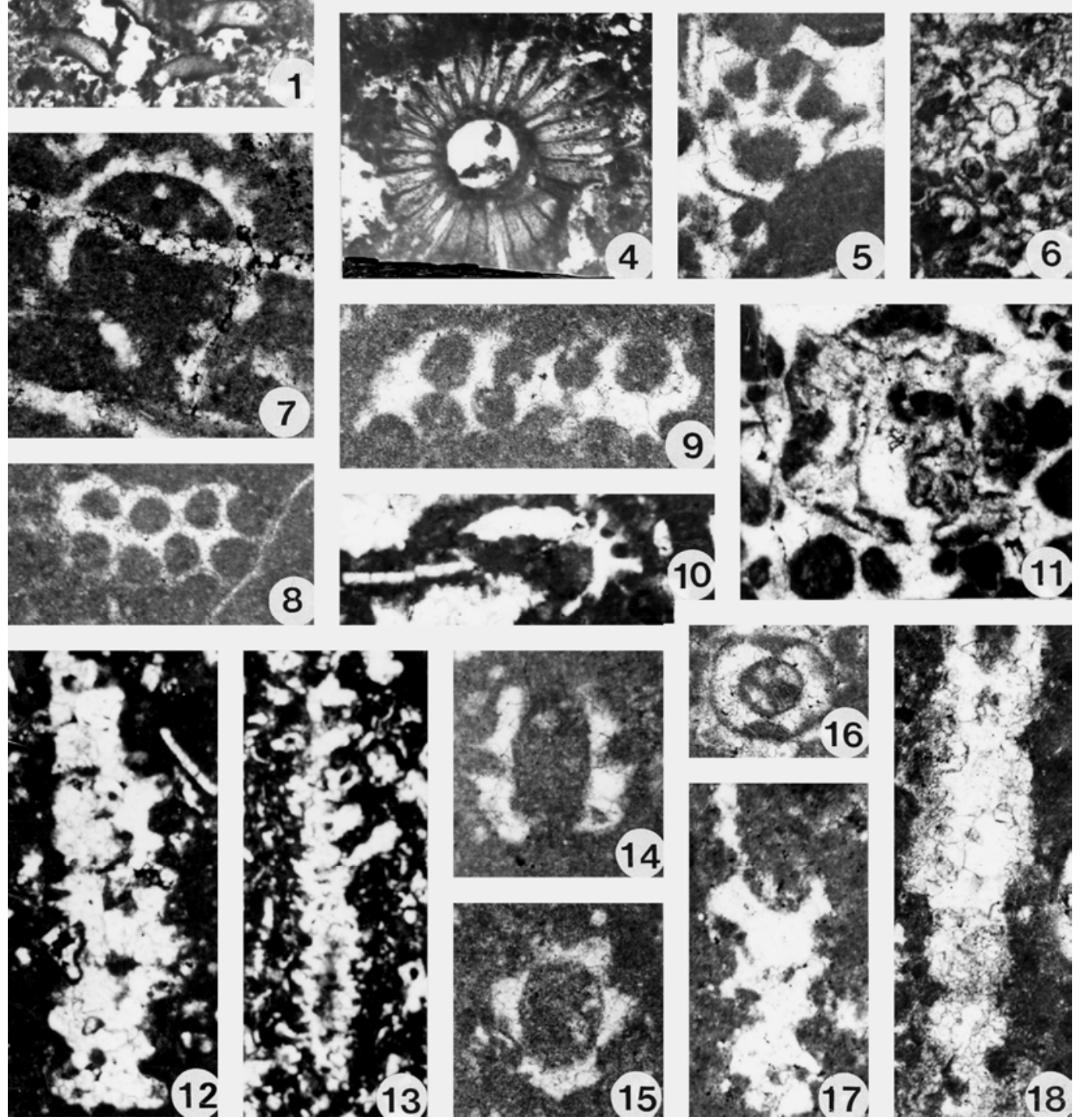

Figs. 1, 2, 4. Clypeina sulcata (ALTH). 1, longitudinal-oblique section; sample N17, X 17. 2, tangential section cutting two successive verticils; sample FSM 16B, X 35. 4, transverse section; sample N17, X 17.

Fig. 3. Salpingoporella annulata CAROZZI. Several specimens in oblique and transverse section; sample FSM 72, X 17.

Figs. 5, 14. Clypeina parasolkani FARINACCI \& RADOIČIĆ. 5, transverse-oblique section; sample FSM 48, X 70. 14, longitudinal-oblique section; sample FSM 38, X70.

Fig. 6. Salpingoporella sp. Transverse section; sample FSM 273, X35.

Fig. 7. ?Humiella sp. Longitudinal section cuting a lateral; sample FSM 72, X 70.

Figs. 8, 9. ?Ioanella sp. Section through pluricyste aggregates; sample N29, X 70.

Fig. 10. ?Clypeina sp. Oblique section; sample N 24, X 70.

Figs. 11-13. Clypeina sp. 11, oblique section; sample N15, X 30. 12, longitudinal-tangential section; sample N 12, X35.13, longitudinal-tangential section N 14, X 17 .

Figs. 15-18. Salpingoporella $c f$. katzeri CONRAD \& RADOIČIĆ. 15, transverse-oblique section; sample FSM $155, X 70$.

16, transverse section; sample FSM 149A, X 70. 17, longitudinal-oblique section; sample FSM 150, X 70.

18, longitudinal-tangential section; sample FSM 150, X70.

For all explanations in the plates 1-3, FSM = Fara San Martino 

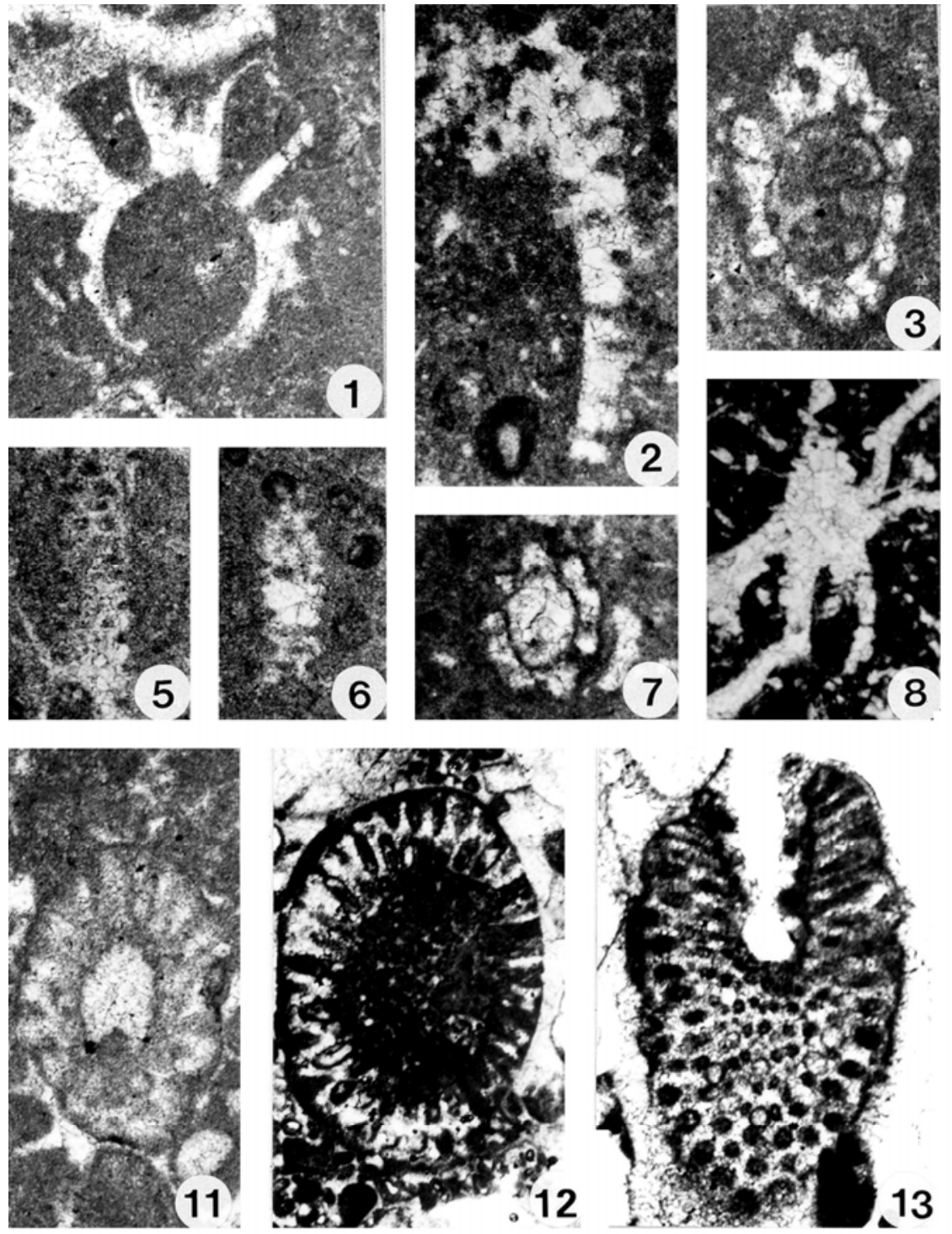
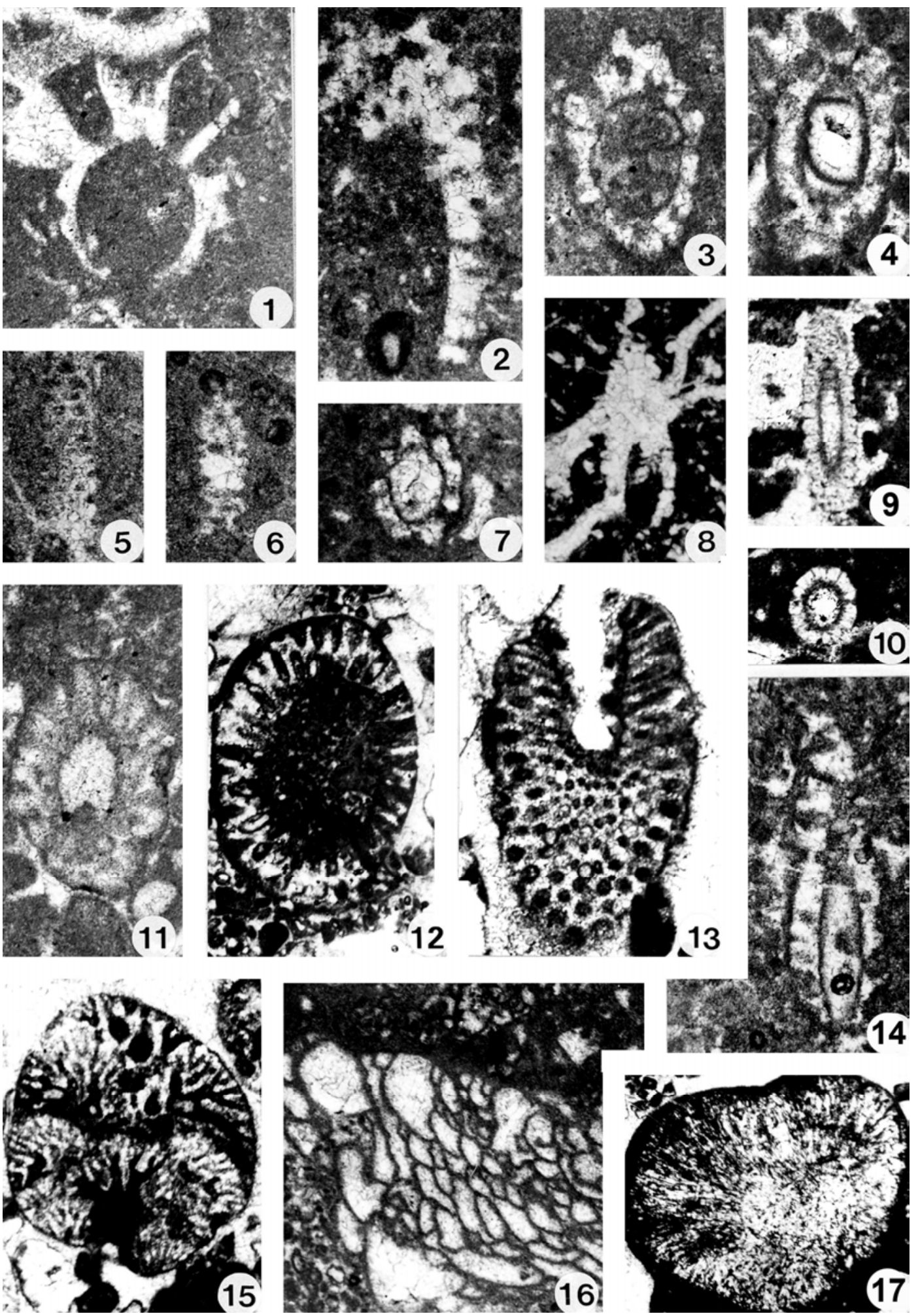

Fig. 1. Clypeina solkani (CONRAD \& RADOIČIĆ). Transverse-oblique section; sample FSM 242, X 70.

Fig. 2. Salpingoporella melitae RADOIČIĆ. Longitudinal-oblique section; sample FSM 155, X 70.

Fig. 3. Salpingoporella sp. Oblique section; sample FSM 155, X 70.

Fig. 4. Cylindroporella? elliptica BAKALOVA. Oblique section; sample FSM 188, X 70.

Figs. 5, 6. Salpingoporella sp. Tangential section (5) and oblique section (6); sample FSM 155, X 70.

Figs. 7, 8. Salpingoporella muehlbergii (LORENZ). Oblique sections; sample FSM 155, 7 X 70; 8 X 35.

Figs. 9, 10. Salpingoporella dinarica RADOIČIĆ. Oblique section (9) and transverse section (10); sample 227, X 70.

Fig. 11. Salpingoporella sp. Oblique section; sample FSM 96B, $X 70$.

Fig. 12. Triploporella marsicana PRATURLON. Transverse-oblique section; sample 208, X17.

Fig. 13. Salpingoporella pygmaea (GUEMBEL). Oblique section; sample 207, X 35.

Fig. 14. Similiclypeina aff. somalica (CONRAD, PEYBERNES \& MASSE). Oblique section; sample FSM 189, X 50.

Fig. 15. Margueritiella densa DRAGASTAN. Sample FSM 209, X 35.

Fig. 16. Bacinella irregularis RADOIČIĆ. Sample FSM 207, X 35.

Fig. 17. ?Nipponophycus sp.. Sample FSM 209, X 17. 

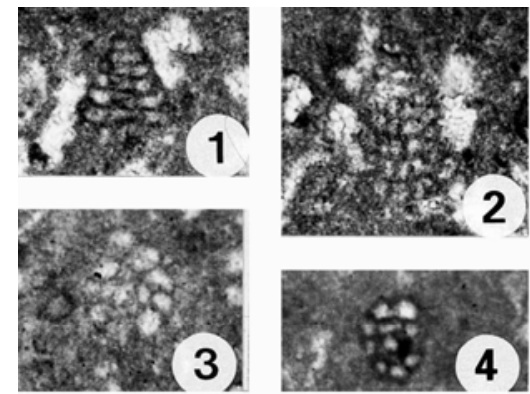

3)
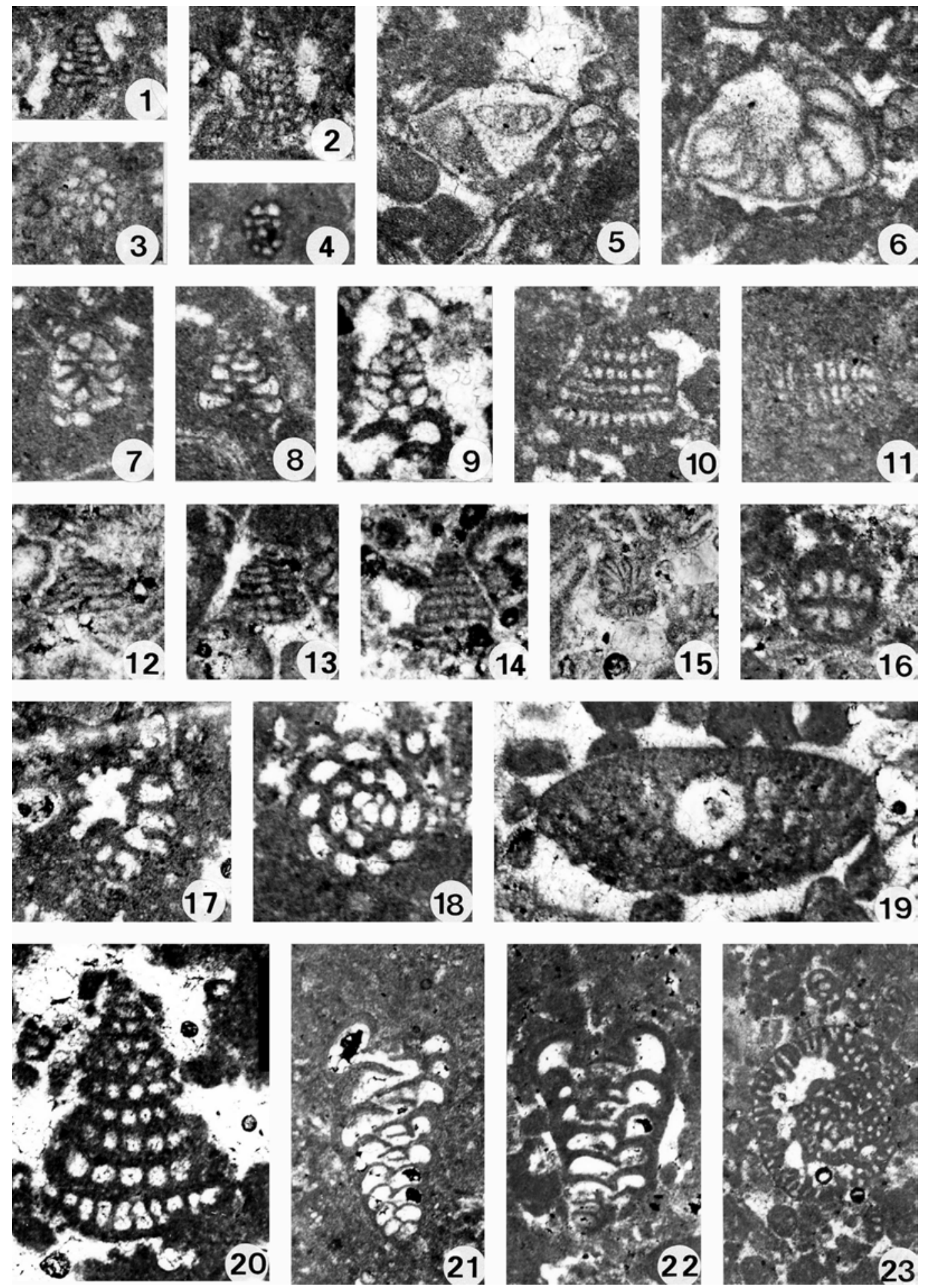

Fig. 1, 2. Montsalevia salevensis (CHAROLLAIS, BROENNIMANN \& ZANINETTI). 1, axial section; sample FSM 105, X 70. 2, longitudinaltangential section; sample FSM 105, X 70.

Figs. 3, 4. Haplophragmoides joukowskyi (CHAROLLAIS, ROENNIMANN \& ZANINETTI). Equatorial section; 3, sample FSM 105; 4 , sample FSM 103, $X 70$.

Fig. 5, 6. Protopeneroplis ultragranulata (GORBACHIK). 5 axial section; 6, equatorial-oblique section; sample FSM $96 B, X 70$.

Figs. 7-9. Campanelulla capuensis DE CASTRO. Oblique sections. 7, 8, sample FSM 242; 9, sample FSM 275 , X 70.

Figs. 10, 11. Vercorsella camposaurii (SARTONI \& CRESCENTI). 10, longitudinal-tangential section; sample FSM 98, X 70. 11, transverse section; sample FSM 97, X70.

Figs. 12-15. Sabaudia minuta (HOFKER). 12, Axial section; 13, 14, longitudinal-tangential sections; 15, transverse-oblique section; sample FSM 190, X70.

Fig. 16. Vercorsella $c f$. scarsellai (DE CASTRO). Transverse section; sample FSM 149, X 70.

Fig. 17. Voloshinoides murgensis LUPERTO SINNI \& MASSE. Transverse-oblique section; sample FSM 227, X 70.

Fig. 18. Debarina hahounerensis FOURCADE, ROUOL \& VILA. Median-transverse section; sample FSM $227, X 70$.

Fig. 19. Palorbitolina lenticularis (BLUMENBACH). Section cutting the embryonal apparatus; sample FSM $208, X 70$.

Fig. 20. Vercorsella laurentii (SARTONI \& CRESCENTI). Longitudinal-tangential section; sample FSM 227, X70.

Figs. 21, 22. Praechrysalidina infracretacea LUPERTO SINNI. Sub-axial sections; 21, sample FSM 97; 22, sample FSM $96, X 35$.

Fig. 23. Pseudocyclammina sp. Sub-equatorial section; sample FSM 209, X 17.

Studia UBB, Geologia, 2007, 52 (2), 45-54 